\title{
Research on Strategies That How to Cultivate the Intercultural Communicative Competences of College Students in College English Teaching
}

\author{
Lizhen Wang \\ Xi’an International University, Xi’an Shaanxi 710077
}

Keyword: Intercultural Communicative Competence; English Teaching; Teaching Model; Strategy

\begin{abstract}
It is an important goal of the college curricular reformation to train students' intercultural communicative competences, is the inevitable requirement of quality education, language and culture, language teaching and culture teaching are closely related. At present, globalization has brought the cultural collisions, which are becoming fiercer, between different countries; it makes English learning becoming more important, and makes the world becoming more closely linked. Different races, different languages, different complexions and different cultures have brought different learning perspectives. It injects fresh blood into English learning, also lets the language and culture to integrate deeply. Under this background, college English teaching requires the teachers to combine the language and the culture in order to improve the overall abilities of the students. However, how to improve the English abilities of the students, and how to grasp the integration of cultural elements in English teaching so as to cultivate the intercultural communicative competences of students has become some important problems that college teachers need to think about carefully. Starting from the connotation of intercultural communication, the author of this paper gives some suggestions that how to cultivate the intercultural communicative competences of college students.
\end{abstract}

To cultivate the intercultural communicative competences of college students, it not only is the requirement of the new curriculum standard, but also the inevitable appeal of current political and economic situation. It makes college students have a better development, contact with different cultures, and improve the students' major abilities and their comprehensive abilities so as to enrich them constantly and get competitiveness. English teaching not only is a kind of simple language teaching that stuff students with vocabularies and grammars, but also an important way to let the students enjoy different cultures, let the students have a deeper comprehension of the situations of other countries, receive baptism from other excellent culture, and feel charm of the different cultures.

\section{Connotation of Intercultural Communicative Competence}

Intercultural Communicative Competence means that different people who have different cultural background, and who also have the intercultural awareness can avoid the pragmatic errors, which are caused by the single dimensional culture, and use the appropriate language to communicate their thoughts and feelings with the people who speak different languages efficiently [1]

As the constantly development of English teaching reformation, at present, college education calls for cultivating the graduates who have the certain skills that can meet the needs of their employers, so it has important realistic significance to enforce the graduates' abilities of getting jobs by enhancing the intercultural communicative competences of students in college English teaching. Every college should constantly highlight the construction of their students' abilities in this field so as to cultivate more practicable graduates that fulfill the needs of our society. Therefore, to cultivate the intercultural communicative competences of the students, it is the important contents of 
construction that English major needs at college ${ }^{[2]}$.

To achieve the changeover of the teaching model from that pays attention to teaching language knowledge, vocabularies, and grammars to that improves students' intercultural communicative competences, colleges should actively promote college teachers to carry out diversified teaching, let the students to be the graduates who have pluralistic abilities for the society. Colleges should let the students master the culture so that improve their students' abilities of using language and their cultural qualities; cultivate the practical abilities of language application, improve the all-round qualities of students so as to the students could masterly accomplish a successful intercultural communication in English, and change these phenomena such as "high scores but low abilities, mute English, poor efficiency " in English teaching, truly achieve the change from examination oriented education to quality education ${ }^{[3]}$.

To cultivate the college students' intercultural communicative competences, it could let the students totally realize the charm of different cultures, understand the history, culture and local customs of other countries so as to the students could comprehend the abundant value and connotation of multiculture. When the students understand the charm of multiculture, and have a good comprehension of the different cultures, they will be attracted by it and improve their interest of studying. It is only fully inspiring the enthusiasms and interests of the students, their subjective initiative could be brought into play. The students change their studying habit from passive to active, half the work with double results. Only when students are interested in study will they concentrate their attention on study; only when the class is lively can the students feel the happiness in study. In English teaching, there are many knowledge points, wide coverage and strong practicability. The teacher will teach a large amount of knowledge in the limited time, it is very easy to make the lesson to be boring and let the students get tired of studying. And especially in the present moment, the students' psychologies that they dislike studying will make the traditional English teaching more difficult. However, intercultural communicative competence could reduce the difficulty of the study and enhance the students' knowledge coverage by changing the teaching model, and by teaching the relevant knowledge points in the more humanized and more appropriate method. It could remedy the limitation of the traditional teaching model, enhance the students' interest of study, and improve their intercultural communicative competences.

\section{Strategies of Cultivating the Students' Intercultural Communicative Competences in English Teaching}

To an independent country, the most important element is culture, culture is the historical deposition of a country, is the base of development in future, is the reflection of a country's soft power, and is the embodiment of a county's strength. Culture is the language, humanity, folk customs, history, ideologies of a country, it is nonrepresentational but idiographic. So, in the cultivation of intercultural communicative competence of the students, of course in the respect of language and culture, if we want to carry out the correct all-round cultural introduction, we must realize the connotation of culture. We could start cultural introduction form language and vocabulary, culture and history, and practical communication. Vocabulary and language are the most important characteristic of a country, vocabulary is the soul of the language of a country, is the direct form of expression. Enforcing vocabulary learning and cultural introduction is the most direct and the fastest way for students to learn language, and it is the best way to improve language sensitivity. Idioms, as the embodiment of a nation's culture, are the most national elements and the essence of cultural development. To introduce the idioms to the students, it not only can let the students enjoy the charm of language, but also the charm of the culture, it also can help the students know the culture of a country, then improve their efficiency of study. When the teachers are teaching, they should extend the words step by step, take idioms for example, idioms show what kind of spirit in foreign cultures, what kind of stories they have, and what kind of wisdom they have, the teachers should correctly guide the students in understanding the cultural differences ${ }^{[4]}$. For the communication, that is teaching the traditional social etiquette and the customs of a country. In English learning, all the social etiquettes and the customs in western countries need the students to 
be known well in order to avoid some awkward situations which are caused by cultural differences. To introduce communicative culture to class, it is for ensure the students are more confident and further in English learning. At last, the students also need to learn the knowledge of culture and history. Teachers should teach the historical information which is involved in text books pertinently. By the explanation of cultural and history, teachers also could make students learning English further, more all-roundly. The historical background is the most profound shadow of a country, only the students understand the cultural background, could the cultural communication abilities of the students be cultivated well in fact.

As the soul, teachers not only are the transmitters who teach knowledge to their students and their guiders in life, but also their example in the daily study. Teachers' teaching abilities, English attainments, and intercultural communicative competences directly determine the students' English learning ability, and also determine the training effects of the students' communicative competence in English ${ }^{[5]}$. During the cultivation of the intercultural communicative competences of the students, the teachers' teaching abilities are the key factors, how to enforce the teachers' controlling abilities in class, how to recompose and teach the different cultures, and how to select the good teaching materials and teaching resources for the students study well, it requires the teachers should have higher career abilities and higher professional abilities in order to set up a good example to the students, give the students excellent lessons, solve the problems of the students, and control the process of the class correctly. Therefore, to cultivate the students, the teachers should do better, should improve their overall abilities in order to ensure the teaching quality and teaching efficiency. The teachers must teach English with full enthusiasm, abundant knowledge and scientific teaching methods in order to ensure the high teaching level. It not only ensures the high efficient study of the students, but also good study of intercultural communicative competence.

The teachers could take the best of video resources; they could introduce some relevant video materials to the students in order to widen the students' scope of knowledge to a certain extent by collecting some appropriate and useful video materials. To the students, they also could totally understand the foreign cultures by the impact of video materials and the classes of stereo and video. The teachers could download some documentaries, pictures, and videos about foreign cultures, so as to the students could have a better understanding about the textbook and have a more intuitive feeling of foreign cultures. For example, teachers could do some PowerPoint courseware according to some factors in British native culture such as historical events, historical figures, and native items and so on, or make a brief teaching video courseware according to some relevant pictures and videos. Combine the video materials and English courses, it can greatly improve the efficiencies, abilities and interests of the students' study, it is the teaching model that fits the developmental need of current times. On the other hand, the applications of video resources also makes more interactions and more communications between the teachers and their students, it constantly improves the students' intercultural communicative competences.

\section{Conclusion}

The different counties, different cultures, different languages are mixing together, are interacting each other in the current situation of globalization. In college English teaching, the teachers not only should do some changes in the teaching contents and teaching models, but also in some other teaching methods. For example, the teachers introduces the different cultures by video resources, and enriches the contents of curriculums, furthermore, the teachers should strengthen their cultural communicative ability in order to correctly guide the students in cultivating their students' intercultural communicative competence. Because of the limited knowledge, the author of this paper welcomes all the scholars and specialists to give some advices about this paper, thanks!

\section{References}

[1] Feng Wenying, Strategies on enhancing the intercultural communicative competences in college oral English teaching under the background of cultural differences between China and western 
countries[J]. Journal of Chifeng University(Philosophy and Social Science Edition), 2010, 02:145-146.

[2] Zhao Ming, Zhang Lidan, Practice and strategies on cultivating the intercultural communicative competences of the students in college English teaching [J]. Journal of Hubei University of Economics: Humanities and Social Sciences, 2010, 06:189-190.

[3] Le Qiong, Chauhan Ashok Kumar, Discussion on cultivating the intercultural communicative competences of the students in college English teaching [J]. JIAOYU TANSUO, 2010, 08:68-69.

[4] Mi Yanqing, Research on college English teaching model that is based on the cultivating of intercultural communicative competence [J]. Journal of Huaihai Institute of Technology (Social Science Edition), 2013, 11:66-69.

[5] Xu Cuiping, Research on cultivating students' intercultural communicative competences in college oral English teaching [J]. Overseas English, 2012, 03:108-109+111. 